\title{
Effect of high glucose on formation of extracellular matrix components by cultured rat heart endothelial cells
}

\author{
M.J. Spiro ${ }^{1,3}$, Q. He ${ }^{2,3}$, M.L. D'Autilia ${ }^{3}$ \\ ${ }^{1}$ Department of Medicine, Harvard Medical School, Boston, Massachusetts, USA \\ 2 Department of Biological Chemistry, Harvard Medical School, Boston, Massachusetts, USA \\ ${ }^{3}$ Joslin Diabetes Center, Boston, Massachusetts, USA
}

\begin{abstract}
Summary In an attempt to define the basis for the microvascular changes observed in diabetic myocardium, a study was undertaken on the effect of elevated glucose on the synthesis by rat heart endothelial cells of the extracellular matrix components, types VI, IV and I collagen, as well as fibronectin. Confluent cultures of these cells, isolated by fluorescenceactivated cell sorting after treatment with rhodamine-labelled acetylated low density lipoprotein, showed a three to fivefold enhancement in the synthesis of type VI collagen after exposure for $48 \mathrm{~h}$ to high glucose (20 to $30 \mathrm{mmol} / \mathrm{l})$, as determined by immunoblot analysis. Increased production of type IV collagen and fibronectin was also observed, but the change was smaller and no effect on type I collagen was found. Measurement of mRNA levels by hybridi-
\end{abstract}

zation with cDNA probes indicated that 48 -h exposure to high glucose significantly increased the level of transcripts for type VI and IV collagens but not for type I collagen. While glucose consumption by endothelial cells in high glucose doubled in the initial 24-h period, utilization returned to normal by $48 \mathrm{~h}$, concomitant with a reduction in GLUT1 transcript levels, suggesting that signals for stimulation of collagen synthesis must be active during the initial period of exposure to elevated glucose levels. [Diabetologia (1995) 38: 430-436]

Key words Rat heart endothelial cells, type VI collagen, type IV collagen, type I collagen, fibronectin, GLUT1, high glucose.
Previous studies from our laboratory have indicated that the periodic acid-Schiff (PAS)-reactive deposits which are observed in the myocardium in the alloxan diabetic rat are characterized by an accumulation of type VI collagen with little or no increase occurring in other components such as types IV and I collagen, fibronectin or laminin $[1,2]$. Although the cells responsible for this increased formation of type VI collagen in the heart in diabetes are not yet known, the presence of the PAS-positive deposits as well as type

Received: 6 July 1994 and in revised form: 26 October 1994

Corresponding author: Dr. M. J. Spiro, Joslin Diabetes Center, One Joslin Place, Boston, Massachusetts, 02215, USA Abbreviations: SDS, Sodium dodecylsulphate; PBS, phosphate-buffered physiological saline; DMEM, Dulbecco's modified Eagle's medium; DEPC, diethylpyrocarbonate; PAS, periodic acid-Schiff.
VI immunoreactivity surrounding the capillaries of the myocardium [1] suggest that the endothelial cells of these small blood vessels may be involved, particularly since the ability of endothelial cells to produce type VI collagen has already been demonstrated using homogeneous populations of cells cultured from the kidney glomerulus [3]. We have therefore undertaken in the present study an evaluation of the effect of high glucose on the capacity of endothelial cells isolated from rat ventricles to synthesize types VI, IV and I collagen, and fibronectin, employing immunoblotting techniques, and have also analysed the level of transcripts for these collagens by hybridization with specific cDNA probes. The data obtained indicated that in the presence of elevated levels of glucose, type VI collagen synthesis was affected to a substantially greater extent than that of types IV or I collagen or fibronectin, consistent with our previous in vivo observations of the diabetic heart. 


\section{Materials and methods}

Endothelial cell isolation. Endothelial cells were prepared from hearts of male Sprague-Dawley rats, 100-125 g (Taconic Farms, Inc., Germantown, N. Y., USA) using a non-perfusion procedure originally developed for myocytes [4]. After digestion of the ventricles with trypsin (Sigma Chemical Co., St. Louis, Mo., USA) and collagenase (CLSII, Worthington, Freehold, N. J., USA) followed by mechanical disruption with tweezers, the cells released were centrifuged on a bovine serum albumin gradient [4] and the fractions containing myocytes and endothelial cells ( $6 \%$ bovine serum albumin layer and pellet) were placed on collagen-coated plates (gelatin from bovine skin, Sigma Chemical Co.) to which the endothelial cells attached during an overnight incubation at $37^{\circ} \mathrm{C}$ in $5 \% \mathrm{CO}_{2}$ atmosphere. Myocytes were removed by vigorous washing with Dulbecco's modified Eagle's medium (DMEM) and the adherent cells were grown on tissue culture plastic in DMEM containing $10 \%$ fetal bovine serum (ICN Biomedicals Inc., Costa Mesa, Calif., USA) as well as 100 units/ml penicillin, $100 \mu \mathrm{g} /$ $\mathrm{ml}$ streptomycin and $0.25 \mu \mathrm{g} / \mathrm{ml}$ amphotericin B. Purification of endothelial cells from mixed cell populations was accomplished by fluorescence-activated cell sorting using an EPICS 752 flow cytometer (Coulter Electronics, Miami, Fla., USA) after overnight incubation with $10 \mu \mathrm{g} / \mathrm{ml}$ of rhodamine-labelled acetylated LDL (DiI-Ac-LDL, Biomedical Technologies, Stoughton, Mass., USA) [5] as previously employed for glomerular endothelial cells [6].

Cell culture for collagen synthesis and RNA extraction. Three days prior to an experiment, the medium on $100-\mathrm{mm}$ plates of endothelial cells (approximately $90 \%$ confluent) was changed to DMEM containing $5 \mathrm{mmol} / \mathrm{l}$ glucose and $5 \%$ fetal bovine serum. This pre-equilibration was followed by a $24-$ or $48-\mathrm{h}$ incubation in medium ( $4 \mathrm{ml}$ ) appropriate for collagen formation which also contained $50 \mathrm{mg} / \mathrm{l}$ of $\beta$-aminoproprionitrile, $50 \mathrm{mg} /$ 1 ascorbic acid and $1 \mathrm{mmol} / 1$ proline as well as varying amounts of additional glucose. At the end of this period the medium was removed and after addition of protease inhibitors [6] was stored at $-20^{\circ} \mathrm{C}$. The plates were then washed with cold phosphate buffered saline (PBS) and in some experiments, matrix was prepared by solubilizing the cell pellet in $1 \%$ SDS-5\% 2-mercaptoethanol by treatment at $100{ }^{\circ} \mathrm{C}$ for $5 \mathrm{~min}$. In other experiments, RNA extraction was carried out using a modified guanidinium isocyanate/phenol/chloroform method [7] using RNAzol (Biotecx Laboratories, Houston, Tex., USA) and the amount present was determined from its absorbance at $260 \mathrm{~nm}$ using a model 240 spectrophotometer (Gilford Instrument Laboratories, Oberlin, Ohio, USA). DNA was determined on the interphase pellets obtained during RNA extraction after their solubilization in $0.1 \mathrm{~N} \mathrm{NaOH}$ using Hoechst dye 33258 [8] (Sigma Chemical Co.) and a TKO-100 fluorometer (Hoeffer Scientific Instruments, San Francisco, Calif., USA).

Polyacrylamide gel electrophoresis and immunoblotting. Aliquots of media or matrix were lyophilized and extracted with $85 \%$ ethanol (v/v) prior to electrophoresis, which was carried out in SDS on vertical polyacrylamide slab gels $(1.5 \mathrm{~mm}$ thick, 12 wells) according to the procedure of Laemmli [9] using a linear 4 to $10 \%$ acrylamide gradient overlaid by a $3.5 \%$ stacking gel. Alternatively, for handling larger aliquots of medium the proteins were precipitated by overnight exposure at $2{ }^{\circ} \mathrm{C}$ to $1.6 \mathrm{~mol} / \mathrm{l}$ ammonium sulphate followed by centrifugation; desalting was accomplished with Centricon 100 microconcentrator (Amicon Co., Beverly, Mass., USA). After transfer to nitrocellulose sheets $[10]$ treatment was performed with antisera against rat type IV [11], type VI [2] or type I collagen [2] or fibronectin [2] followed by ${ }^{125} \mathrm{I}$-labelled protein $\mathrm{A}$ as previously described [3]. Radioactive bands were visualized by autoradiography using X-Omat AR film (Eastman Kodak, Rochester, N. Y., USA) and the amount of each component was determined by laser densitometry (Molecular Dynamics, Sunnyvale, Calif., USA) of the radioautograph. While for type IV collagen and fibronectin the single bands obtained were quantitated, for type VI collagen the densities of the $\alpha 3$ and the comigrating $\alpha 1$ and $\alpha 2$ bands were either measured separately or summed for total type VI estimation; for type I collagen, the total of the four procollagen bands observed was used. Relative density was calculated from the ratio of the value of each experimental sample to the average of control samples $(5 \mathrm{mmol} / \mathrm{l}$ glucose) blotted onto the same membrane.

Preparation and radiolabelling of $c D N A$. The clones for mouse $\alpha 1(I V)$ collagen (pPE123) were kindly provided by Dr. M. Kurkinen of the University of Medicine and Dentistry of New Jersey, Piscataway, N.J., USA, [12] and for human $\alpha 1$ (VI) collagen (p18) by Dr. M.-L. Chu, Thomas Jefferson University, Philadelphia, Pa., USA [13]; clone HF677 for human $\alpha 1$ (I) collagen [14] was a gift of Dr. F. Ramirez, SUNY Health Science Center, Brooklyn, N. Y., USA, and p-rlf-1 for rat fibronectin [15] was from Dr. R. Hynes (Massachusetts Institute of Technology, Cambridge, Mass., USA). Clones of Escherichia coli containing cDNA for the human facilitative glucose transporters GLUT1, GLUT2, GLUT3 and GLUT4 were obtained from ATCC, Rockville, Md., USA (catalogue numbers 59630 , 61612,61614 , and 61616 , respectively). After being grown in $E$. coli, the plasmids were isolated on Qiagen tip-500 columns (Qiagen, Chatsworth, Calif., USA) and digested with appropriate restriction enzymes prior to electrophoresis on $1.5 \%$ low melting point agarose gels (BioRad Laboratories, Richmond, Calif., USA). The cDNA of appropriate size was released using GELase (Epicentre Technologies, Madison, Wis., USA), precipitated in $75 \%$ ethanol and $0.25 \mathrm{~mol} / 1$ ammonium acetate and stored in TE pH 8.0 solution (TE) at $-20^{\circ} \mathrm{C}$. Actin cDNA (chicken) was purchased from Oncor, Inc. (Gaithersburg, Md., USA). Probes were labelled with $\left.{ }^{32} \mathrm{P}\right] \mathrm{dCTP}$ (NEN Research Products, Boston, Mass., USA) by using the Megaprime DNA labelling system (Amersham, Arlington Heights, Ill., USA) and after addition of $100 \mu \mathrm{g} / \mathrm{ml}$ salmon sperm DNA (Sigma) were purified by high performance liquid chromatography on a TSK2500PWXL column [3].

Hybridization of RNA. Samples of oligo(dT)-isolated mRNA (Biotecx Laboratories, Houston, Tex., USA) were electrophoresed on $1 \%$ agarose gel containing $2.2 \mathrm{~mol} / 1$ formaldehyde [16], and then transferred to nylon membranes (Nytran, Schleicher and Schuell, Keene, N.H., USA). For dot blotting, aliquots of RNA (10 and $20 \mu \mathrm{g}$ ) were denatured at $65^{\circ} \mathrm{C}$ for $15 \mathrm{~min}$ in $50 \%$ formamide, $7 \%$ formaldehyde and $1 \times \mathrm{SSC}$ $(0.15 \mathrm{~mol} / 1 \mathrm{NaCl}, 0.015 \mathrm{~mol} / 1$ sodium citrate, $\mathrm{pH} 7.0)$ [14] and then applied to Nytran filters using a Minifold 1 apparatus (Schleicher and Schuell). Prehybridization was performed [16] in $5 \times$ Denhardt's solution ( $1 \mathrm{~g} / 1$ each of Ficoll, polyvinyl pyrollidone and bovine serum albumin), formamide $(500 \mathrm{ml} /$ 1), $1 \mathrm{~g} / 1 \mathrm{SDS}, 200 \mathrm{mg} / 1$ salmon sperm DNA and $5 \times \mathrm{SSPE}$ [in $\mathrm{mmol} / 1, \mathrm{NaCl}, 750 ; \mathrm{NaH}_{2} \mathrm{PO}_{4}, 50 ;$ EDTA, 5] for $4 \mathrm{~h}$ at $42^{\circ} \mathrm{C}$ in an oven (Red Roller, Hoeffer). The membranes were then hybridized with the $\left[{ }^{32} \mathrm{P}\right]$-labelled probes $\left(0.5-1 \times 10^{7} \mathrm{cpm} / \mathrm{ml}\right)$ for $20 \mathrm{~h}$ in $2.5 \times$ Denhardt's, containing the reagents listed above, washed three times with $2 \times \mathrm{SSC}$ and $1 \mathrm{~g} / \mathrm{S} \mathrm{SDS}$ at $22^{\circ} \mathrm{C}$ followed by a final wash in $0.1 \times \mathrm{SSC}$ and the SDS at $62^{\circ} \mathrm{C}$ for types IV and VI collagen and $42^{\circ} \mathrm{C}$ for the other probes prior to radioautography at $-80^{\circ} \mathrm{C}$ using $\mathrm{X}$-Omat $\mathrm{AR}$ film (East- 


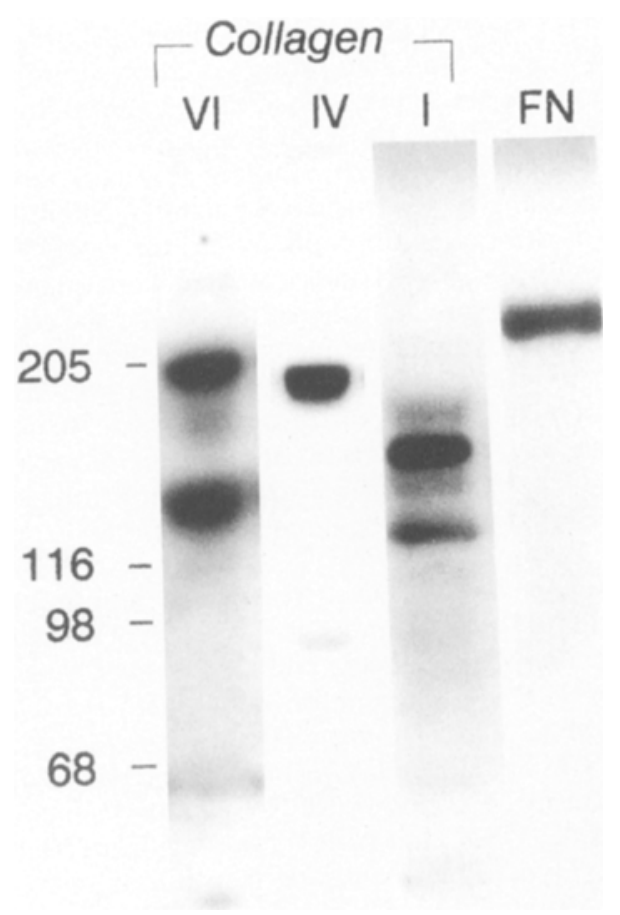

Fig. 1. Identification by immunoblotting of types VI, IV and I collagen and fibronectin. Confluent cultures of rat myocardial endothelial cells were incubated for $48 \mathrm{~h}$ as described in the Methods section; aliquots of medium were electrophoresed, blotted onto nitrocellulose and reacted with anti-rat type VI, IV or I collagen or fibronectin prior to treatment with ${ }^{125} \mathrm{I}-\mathrm{la}$ belled protein A. Molecular weight markers run on the same gel were myosin (205), $\beta$-galactosidase (116), phosphorylase $\mathrm{B}$ (98) and bovine serum albumin $(68 \mathrm{kDa})$

man Kodak). Signal intensities were quantitated by laser densitometry and expressed as relative units after correction for the actin mRNA densities determined on the same sheet.

Statistical analysis.

Statistics were performed by the two-tailed Student's $t$-test.

\section{Results}

Synthesis of collagens and fibronectin by myocardial endothelial cells. The cell populations remaining adherent to the collagen-coated plates after removal of cardiac myocytes were highly enriched in endothelial cells which could be readily purified by fluorescence-activated cell sorting. After sorting, the homogenous endothelial cells grew as cobblestone monolayers and uniformly exhibited uptake of rhodaminelabelled acetylated LDL.

Analysis of endothelial cell culture medium by immunoblotting demonstrated the secretion of types VI, IV and I collagen, as well as fibronectin (Fig. 1). The electrophoretic pattern of type VI was similar to that observed for glomerular cells [3] with $\alpha 1$ and $\alpha 2$ bands comigrating at $150 \mathrm{kDa}$ and the $\alpha 3$ band at
$205 \mathrm{kDa}$. Type IV collagen was represented by only the $\alpha 1$ band, as has also been observed for calf glomerular epithelial, mesangial and endothelial cells [6], as well as for rat mesangial cells [3]. Several type I procollagen bands were detected and the single fibronectin band had an apparent $\mathrm{M}_{\mathrm{r}}$ of $220 \mathrm{kDa}$ (Fig. 1); no reaction occurred between the anti-rat fibronectin used for these assays and bovine fibronectin, which is present in the culture medium. Examination of the matrix demonstrated similar electrophoretic patterns for these proteins.

Effect of glucose concentration on collagen and fibronectin synthesis. Studies which were performed to determine the temporal response to elevated glucose indicated that while no change in synthesis of type VI collagen was observed during the first 24 -h period (Fig. 2), by $48 \mathrm{~h}$ enhanced collagen formation had occurred at both 20 and $30 \mathrm{mmol} / 1$ concentrations (Fig.2). Subsequent studies were therefore conducted for $48 \mathrm{~h}$.

A comparison was also made between the effect of high glucose on the amount of the type VI collagen secreted and that associated with the matrix. Although exposure to $20 \mathrm{mmol} / 1$ or $30 \mathrm{mmol} / 1$ glucose led to substantial and significant increases in the total medium type VI collagen, the elevations observed in the matrix were less dramatic and did not achieve significance (Fig. 3). This finding is not unexpected, since while the secreted fraction represented components synthesized only during the experimental period, those in the matrix were also formed during growth and pretreatment, minimizing any effect from the test conditions. For this reason the remainder of our studies focused on secreted proteins.

Marked differences were observed in the response to elevated glucose of the several components studied. When the subunits of type VI were analysed separately, the greatest effect was found in the comigrating $\alpha 1$ plus $\alpha 2$ components, which increased more than fivefold at either 20 or $30 \mathrm{mmol} / \mathrm{l}$ glucose, while the $\alpha 3$ subunit was enhanced two to threefold (Fig.4). For type IV collagen and fibronectin, elevations of 1.5 to twofold were observed while for type I collagen, high glucose appeared to have no effect (Fig. 5).

The enhancement observed in synthesis of these proteins could not be accounted for by changes in cell number since the amount of DNA per plate was unaffected by the glucose concentration of the medium (Table 1); the cells used were confluent at the beginning of the experiments and therefore only small changes in cell number (DNA) occurred between 24 and $48 \mathrm{~h}$ (Table 1 ).

Effect of glucose on endothelial collagen mRNA levels. When endothelial cell poly $(\mathrm{A}+) \mathrm{RNA}$ was electrophoresed, blotted and hybridized with $\left[{ }^{32} \mathrm{P}\right]$ label- 


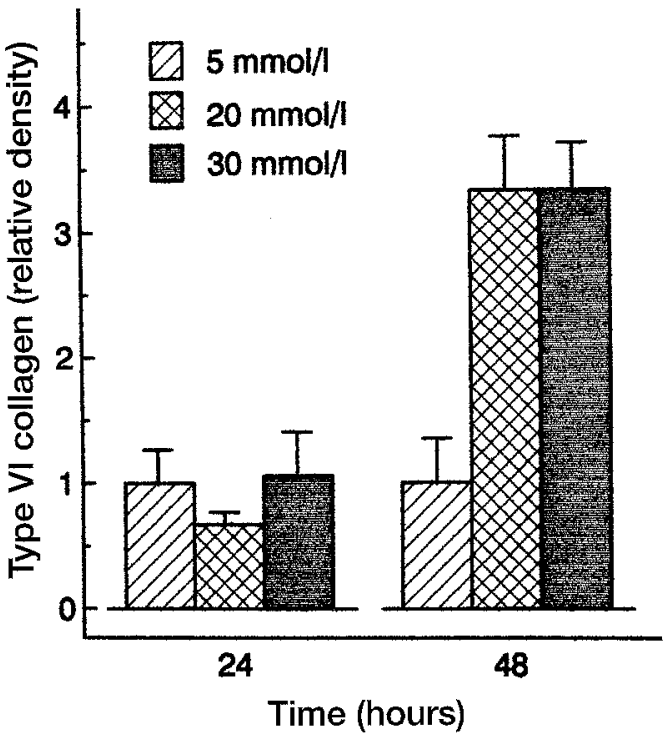

Fig. 2. Effect of elevated glucose on type VI collagen formation at 24 and $48 \mathrm{~h}$. Confluent rat heart endothelial cells were incubated in duplicate as described in the Methods section at the indicated glucose concentrations; aliquots were taken at $24 \mathrm{~h}$ and again at $48 \mathrm{~h}$ for electrophoresis and immunoblotting. After laser densitometric analysis of the radioautographs, the comigrating $\alpha 1$ and $\alpha 2$ plus the $\alpha 3$ bands of type VI collagen were summed for each sample; relative density was calculated from the ratio of the experimental sample to the average of the control $(5 \mathrm{mmol} / \mathrm{l})$ sample blotted on the same sheet. Bars indicate the SEM

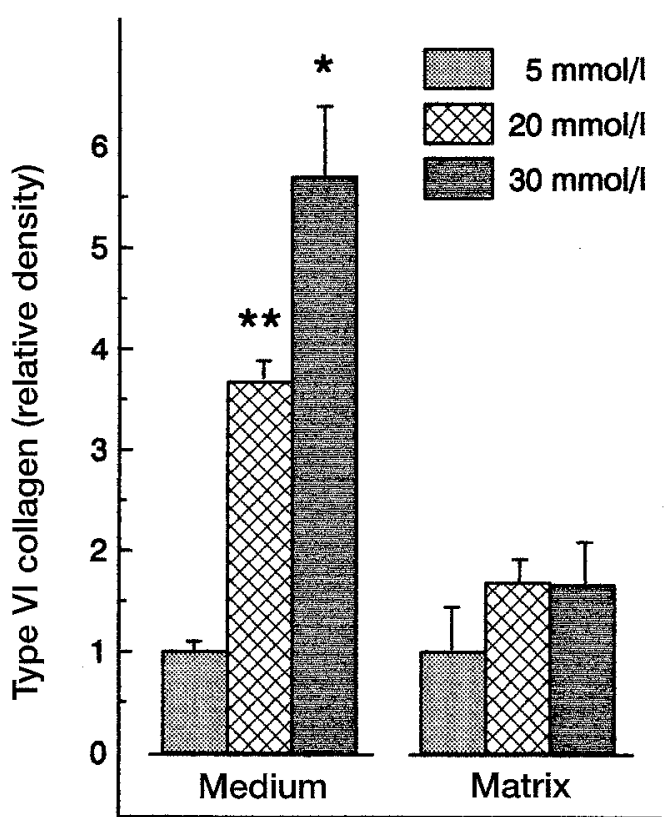

Fig. 3. Comparison of the effect of elevated glucose on medium and matrix type VI collagen. Confluent rat heart endothelial cells were incubated in triplicate at the indicated glucose concentrations for $48 \mathrm{~h}$; aliquots of the medium as well as of the SDS-mercaptoethanol solubilized cell/matrix pellet were electrophoresed and immunoblotted. Relative density was calculated as described in Figure 2. Bars indicate SEM; $* p<0.01$; $* * p<0.001$

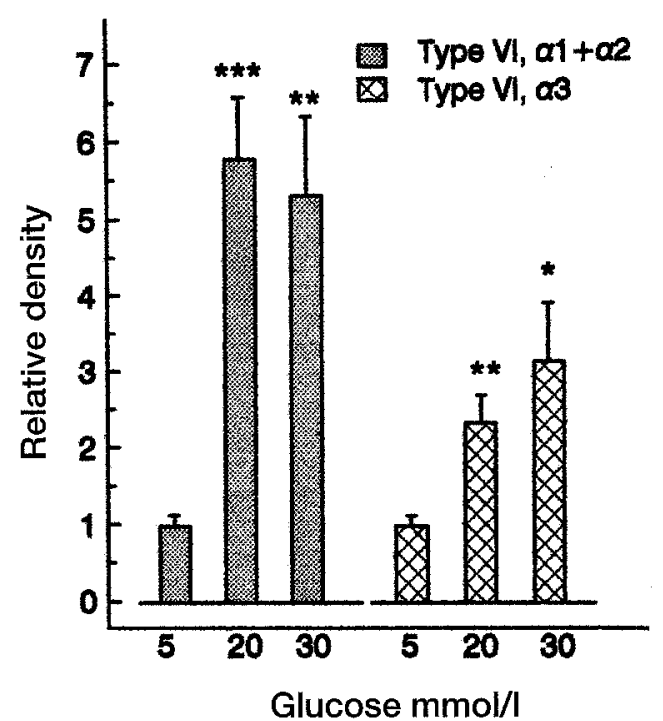

Fig.4. Comparison of the effect of elevated glucose on subunits of type VI collagen. Confluent rat myocardial endothelial cells were incubated for $48 \mathrm{~h}$ as described in the Methods section and aliquots of the medium were analysed by immunoblotting. After laser densitometry the relative absorbance of the bands were determined compared to $5 \mathrm{mmol} / 1$ glucose samples blotted onto the same membrane; the $\alpha 1$ and $\alpha 2$ subunits which comigrate at $150 \mathrm{kDa}$ were calculated together while $\alpha 3(205 \mathrm{kDa})$ was measured separately. Bars indicate SEM; $* p<0.025 ; * * p<0.005 ; * * * p<0.001$. Eight samples were analysed at each glucose concentration. DNA determinations performed on six plates each under the same conditions indicated no effect of elevated glucose, with the $5 \mathrm{mmol} / \mathrm{l} \mathrm{val}-$ ue being $34.5 \pm 1.2 ; 20 \mathrm{mmol} / \mathrm{l}$ being $36.9 \pm 2.1$; and the $30 \mathrm{mmol} / 1$ value, $39 \pm 2.9 \mu \mathrm{g} /$ plate

led probe for $\alpha 1$ (IV) collagen, bands at 6.5 and $7.3 \mathrm{~kb}$ were detected, with the smaller being comparable to the single band reported for umbilical vein endothelial cells [17]. Hybridization with the cDNA for type I $\alpha 1$ demonstrated transcripts at 5.4 and $6.5 \mathrm{~kb}$, consistent with values reported previously [14]; and for $\alpha 1$ (VI) collagen the anticipated band at $4.6 \mathrm{~kb}$ [13] was found. In the first $24-\mathrm{h}$ period, little effect was observed from elevated glucose on the mRNA levels for the collagens, measured by the dot blotting procedure (Fig. 6); however, by $48 \mathrm{~h}$ statistically significant increases to approximately 1.5 times the control levels were observed in the message for both $\alpha 1$ (VI) and a1(IV) collagen chains. No effect was observed on the mRNA for type I collagen.

Effect of high glucose on endothelial glucose consumption and GLUT1 mRNA levels. Upon exposure of confluent endothelial cells to elevated concentrations of glucose, a high consumption of this sugar was observed only in the first 24-h-period (Table 1), suggesting that the facilitative transporter of these cells was down-regulated by the high glucose. Hybridization of a Northern blot of endothelial cell poly $(\mathrm{A}+)$ RNA with ${ }^{32}$ P-labelled GLUT1 cDNA in- 


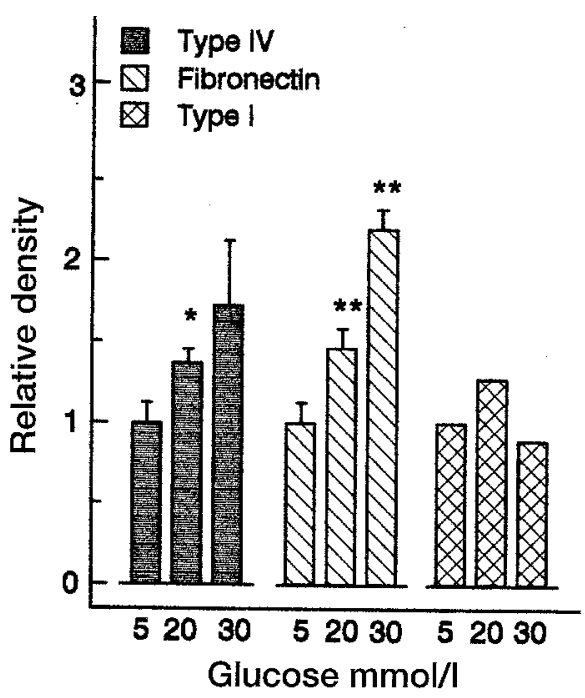

Fig. 5. Comparison of the effect of elevated glucose on types IV and I collagen as well as fibronectin. Confluent rat myocardial endothelial cells were incubated for $48 \mathrm{~h}$ as described in the Methods section and aliquots of the medium were analysed by immunoblotting. After laser densitometry the relative absorbance of the bands (Fig. 1) were determined compared to $5 \mathrm{mmol} / \mathrm{l}$ glucose samples blotted onto the same membrane. For type IV collagen, seven samples were analysed at each glucose concentration; for fibronectin, five; and for type I collagen, two. As indicated in the legend to Figure 4, no change in DNA was observed under these experimental conditions. Bars indicate SEM; ${ }^{*} p<0.025 ; * * p<0.005$

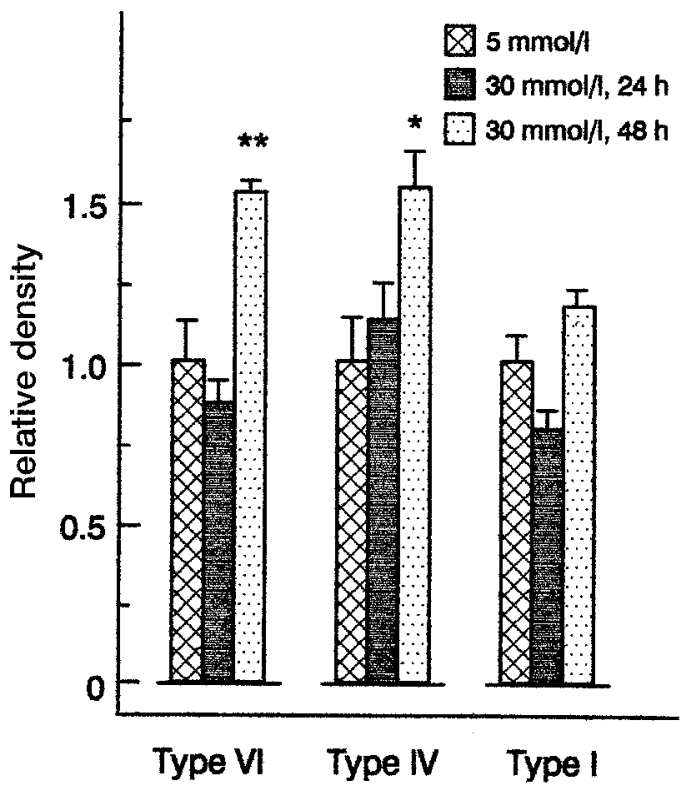

Fig. 6. Response of collagen mRNAs to elevated glucose. Confluent rat myocardial endothelial cells were incubated for 24 or $48 \mathrm{~h}$ in 5 or $30 \mathrm{mmol} / \mathrm{l}$ glucose as described in the Methods section prior to preparation of RNA. After hybridization of dot blots with radiolabelled collagen cDNA probes, the density of each was corrected for actin determined on the same blot and expressed relative to the $5 \mathrm{mmol} / 1$ samples. Five samples each were performed; the DNA and glucose consumption are shown in Table $1 ; * p<0.05 ; * * p<0.005$ compared to $5 \mathrm{mmol} / 1$ samples
Table 1. Effect of elevated glucose concentration on myocardial endothelial cell glucose consumption, GLUT1 transcripts, and DNA content

\begin{tabular}{|c|c|c|c|}
\hline Condition & $\begin{array}{l}\text { Glucose } \\
\text { consumption } \\
\left(\mu \mathrm{g} \cdot \mu \mathrm{gDNA}{ }^{-1} \text {. }\right. \\
\left.24 \mathrm{~h}^{-1}\right)\end{array}$ & $\begin{array}{l}\text { GLUT } 1 \\
\text { mRNA } \\
\text { relative } \\
\text { density }\end{array}$ & $\begin{array}{l}\text { DNA } \\
\mu \mathrm{g} / \text { plate }\end{array}$ \\
\hline $5 \mathrm{mmol} / 1,24 \mathrm{~h}$ & $115 \pm 0.5$ & $1.0 \pm 0.1$ & $47 \pm 2$ \\
\hline $30 \mathrm{mmol} / 1,24 \mathrm{~h}$ & $202 \pm 2.7^{\mathrm{a}}$ & $0.49 \pm 0.1^{\mathrm{b}}$ & $50 \pm 4$ \\
\hline $5 \mathrm{mmol} / 1,48 \mathrm{~h}$ & $105 \pm 1.2$ & $1.0 \pm 0.1$ & $54 \pm 1$ \\
\hline $30 \mathrm{mmol} / 1,48 \mathrm{~h}$ & $62 \pm 0.4$ & $0.73 \pm 0.1^{\mathrm{a}}$ & $59 \pm 3$ \\
\hline
\end{tabular}

For each condition, five $100-\mathrm{mm}$ plates were used; the cells which had been cultured until nearly confluent in DMEM containing $5 \%$ fetal bovine serum and $5 \%$ NuSerum at $5 \mathrm{mmol} / \mathrm{l}$ glucose were changed to DMEM containing $2.5 \%$ fetal bovine serum and $2.5 \%$ NuSerum and $5 \mathrm{mmol} / 1$ glucose. After pre-equilibration for 2 days, elevated glucose concentration was added to indicated plates either 48 or $24 \mathrm{~h}$ prior to harvesting the cells for RNA isolation and measurement of DNA; for the $48-\mathrm{h}$ incubation, fresh medium was added at $24 \mathrm{~h}$

Glucose consumption is indicated for the $24-\mathrm{h}$ period prior to harvesting cells

The density of the GLUT1 on radioautograms has been corrected for the actin density on the same blot

${ }^{\mathrm{a}} p<0.05 ;{ }^{\mathrm{b}} p<0.005$, compared to $5 \mathrm{mmol} / \mathrm{l}$ glucose samples

dicated the presence of a transcript at $2.6 \mathrm{~kb}$, similar to that reported for other cultured cells $[18,19]$, including aortic endothelial cells [20]. No bands were detected with cDNAs for GLUT2, GLUT3 or GLUT4. Measurement by the dot blotting procedure indicated that already by $24 \mathrm{~h}$ the level of GLUT1 mRNA was significantly reduced and this reduction was maintained over the next 24 -h period (Table 1). This would indicate that any signals caused by elevated glucose levels must be generated during the first few hours of exposure.

\section{Discussion}

Since the initial description of the diabetic glomerular lesions by Kimmelstiel and his collaborators [21] the kidney has been the major focus of studies on the microvascular complications of this disease despite the fact that similar changes occur in the small blood vessels of the heart, a condition termed diabetic cardiomyopathy $[22,23]$. While multiple changes have been demonstrated for the diabetic glomerulus, including increased amounts of type IV and type VI collagen as well as reductions in laminin and heparan sulphate proteoglycan $[24,25]$, the microvascular complications in the heart appear to represent primarily an increase in type VI, the microfibrillar collagen, which we found to be responsible for the PAS reactive deposits observed surrounding the capillaries $[1,2]$. This difference in tissue response may reflect the constellation of cells present in myocardial capillaries (endothelial cells and pericytes) and glo- 
meruli, which contain epithelial cells in addition to endothelial and mesangial cells; previous studies from our laboratory have indicated that only the latter two cell types form type VI collagen, while all three synthesize type IV.

Most previous investigations on the effect of glucose on collagen synthesis by cells in culture have focused on type IV and have found an approximately twofold increase in this protein, whether the elevated glucose was present during the entire growth period of endothelial $[17,26]$ or mesangial [27-29] cells or when exposure of confluent glomerular epithelial, mesangial or endothelial cells was only for short periods of time $[3,6]$. The influence of elevated glucose on type VI collagen has previously been studied only with rat glomerular mesangial cells and in that system the extent of stimulation was similar for both types VI and IV collagens, even though marked differences were observed in other aspects of the response, with type VI reflecting more rapidly both increased and normalized glucose levels, and only type IV being enhanced by addition of the glucose metabolite pyruvate or by the presence of aldosterone or IGF-1 [3]. In the present study of myocardial endothelial cells, the most dramatic difference found between types VI and IV collagen was not temporal but rather the extent of the stimulation, with the much more marked increases in type VI being consistent with the specific elevation of this collagen observed in vivo in the heart of the alloxan-diabetic rat $[1,2]$.

The manner in which glucose metabolism stimulates formation of the various matrix components is still not clear but it seems likely, given the dissimilar response of type IV and VI collagen to pyruvate [3] that the various enzymatic steps may provide unique signals, some of which regulate synthesis of these proteins. Therefore, the changes observed in the extracellular matrix of each tissue in diabetes will reflect the metabolism of the specific cells and comparative studies of cell response may help to dissect the mechanisms involved.

The observation that glucose consumption by rat heart endothelial cells returns to normal after $24 \mathrm{~h}$ of exposure to high glucose suggests that any signal generation stimulated by excess glucose metabolism occurs soon after treatment begins. This observed reduction in glucose uptake with time is consistent with previous reports of hexose transport down-regulation in cultured cells [30] and mRNA levels for GLUT1 have been found to be consistent with the transport changes observed, namely being increased after glucose starvation and conversely decreased after treatment with more than $15 \mathrm{mmol} / 1$ glucose [31-33]. Although glucose metabolism is required for this regulation of hexose transport, the exact signals for altered transcription are still unclear. Just as collagens IV and VI are differentially regulated by glucose and metabolites such as pyruvate [3], transport down-regulation is promoted by glucosamine and mannose but not fructose [30], which would be expected to enter the metabolic pathway at the same point. Concomitant investigation of regulation of both extracellular matrix formation and hexose transport may therefore provide valuable clues to the early events occurring after exposure of cells to elevated glucose concentrations.

Acknowledgements. This work was supported by grant HL31315 from the National Institutes of Health; fluorescence-activated cell sorting was performed by a core facility of the Joslin DERC grant from the National Institutes of Health (DK36836).

\section{References}

1. Spiro MJ, Kumar BRR, Crowley TJ (1992) Myocardial glycoproteins in diabetes: type VI collagen is a major PAS-reactive extracellular matrix protein. J Mol Cell Cardiol 24:397-410

2. Spiro MJ, Crowley TJ (1993) Increased rat myocardial type VI collagen in diabetes mellitus and hypertension. Diabetologia 36:93-98

3. Wakisaka M, Spiro MJ, Spiro RG (1994) Synthesis of type VI collagen by cultured glomerular cells and comparison of its regulation by glucose and other factors with that of type IV collagen. Diabetes 43:95-103

4. Weishaar RE, Simpson RU (1986) Isolation, stages of differentiation, and long term maintenance of adult rat myocytes. Cell Biol Internat Reports 10:745-753

5. Voyta JC, Via DP, Butterfield CE, Zetter BR (1984). Identification and isolation of endothelial cells based on their increased uptake of acetylated low density lipoprotein. J Cell Biol 99:2034-2040

6. Danne T, Spiro MJ, Spiro RG (1993) Effect of high glucose on type IV collagen production by cultured glomerular epithelial, endothelial, and mesangial cells. Diabetes 42:170177

7. Chomczynski P, Sacchi N (1987) Single-step method of RNA isolation by acid guanidine thiocyanate-phenolchloroform extraction. Anal Biochem 162:156-159

8. Downs TR, Wilfinger WW (1983) Fluorometric quantification of DNA in cells and tissue. Anal Biochem 131:538-547

9. Laemmli UK (1970) Cleavage of structural proteins during the assembly of the head of bacteriophage T4. Nature (Lond) 277:680-685

10. Towbin H, Staehelin T, Gordon J (1979) Electrophoretic transfer of proteins from polyacrylamide gels to nitrocellulose sheets: procedure and some applications. Proc Natl Acad Sci USA 76:4350-4354

11. Mohan, PS, Spiro RG (1986) Macromolecular organization of basement membranes: characterization and comparison of glomerular basement membrane and lens capsule components by immunochemical and lectin affinity procedures. J Biol Chem 261:4328-4336

12. Muthukumaran G, Blumberg B, Kurkinen M (1989) The complete primary structure for the $\alpha 1$-chain of mouse collagen IV. J Biol Chem 264:6310-6317

13. Chu M-L, Mann K, Deutzmann R et al. (1987) Characterization of three constituent chains of collagen type VI by peptide sequences and cDNA clones Eur J Biochem 168:309-317 
14. Chu M-L, Myers JC, Bernard MP, Ding J-F, Ramirez R (1982) Cloning and characterization of five overlapping cDNAs specific for the human pro alpha 1(I) collagen chain. Nucleic Acids Res 10:5925-5933

15. Schwarzbauer JE, Tamkun JW, Lemischka IR, Hynes RO (1983) Three different fibronectin mRNAs arise by alternative splicing within the coding region. Cell 35:421-431

16. Sambrook J, Fritsch EF, Maniatis T (1989) Extraction, purification and analysis of messenger RNA from eukaryotic cells. In: Nolan C (ed) Molecular cloning: a laboratory manual. Cold Spring Harbor Laboratory Press, Cold Spring Harbor, New York, pp 7.1-7.87

17. Cagliero E, Roth T, Roy S, Maiello M, Lorenzi M (1991) Expression of genes related to the extracellular matrix in human endothelial cells. J Biol Chem 266:14244-14250

18. Thorens B, Charron MJ, Lodish HF (1990) Molecular physiology of glucose transporters. Diabetes Care 13:209-218

19. Fukumoto H, Seino S, Imura H, Seino Y, Bell GI (1988) Characterization and expression of human HepG2/erythrocyte glucose-transporter gene. Diabetes 37:657-661

20. Pekala P, Marlow M, Heuvelman D, Connolly D (1990) Regulation of hexose transport in aortic endothelial cells by vascular permeability factor and tumor necrosis factor$\alpha$, but not by insulin. J Biol Chem 265:18051-18054

21. Kimmelstiel P, Kim OJ, Beres J (1962) Studies on renal biopsy specimens, with the aid of the electron microscope. I. Glomeruli in diabetes. Am J Clin Pathol 45:270-279

22. Rubler S, Dlugash J, Yuceoglu YZ, Kumral T, Branwood AW, Grishman A (1972) A new type of cardiomyopathy associated with diabetic glomerulosclerosis. Am J Cardiol 30:595-602

23. Ledet T (1976) Diabetic cardiopathy. Quantitative histological studies of the heart from young juvenile diabetics. Acta Path Microbiol Scand 84:421-428
24. Spiro RG (1988) Pathogenesis of diabetic glomerulopathy: a biochemical view. In: Mogensen CE (ed) The kidney and hypertension in diabetes mellitus. Nijhoff, Boston, pp 117130

25. Mohan PS, Carter WG, Spiro RG (1990) Occurrence of type VI collagen in extracellular matrix of renal glomeruli and its increase in diabetes. Diabetes 39:31-37

26. Cagliero E, Roth T, Sayon R, Lorenzi M (1991) Characteristics and mechanisms of high-glucose-induced overexpression of basement membrane components in cultured human endothelial cells. Diabetes 40:102-110

27. Ayo SH, Radnik RA, Glass WF II, Garoni JA, Rampt ER, Appling DR, Kreisberg JI (1991) Increased extracellular matrix synthesis and mRNA in mesangial cells grown in high-glucose medium. Am J Physiol 260:F185-F191

28. Haneda M, Kikkawa R, Horide N et al. (1991) Glucose enhances type IV collagen production in cultured rat glomerular mesangial cells. Diabetologia 34:198-200

29. Pugliese G, Pricci F, Pugliese F et al. (1994) Mechanisms of glucose-enhanced extracellular matrix accumulation in rat glomerular mesangial cells. Diabetes 43(3):478-490

30. Ullrey DB, Franchi A, Pouyssegur J, Kalckar HM (1982) Down-regulation of the hexose transport system: metabolic basis studied with a fibroblast mutant lacking phosphoglucose isomerase. Proc Natl Acad Sci USA 79:3777-3779

31. Walker PS, Donovan JA, Van Ness BG, Fellows RE, Pessin JE (1988) Glucose-dependent regulation of glucose transport activity, protein, and $\mathrm{mRNA}$ in primary cultures of rat brain glial cells. J Biol Chem 263:15594-15601

32. Ohta T, Isselbacher KJ, Rhoads DB (1990) Regulation of glucose transporters in LLC-PK 1 cells: effects of D-glucose and monosaccharides. Mol Cell Biol 10:6491-6499

33. Wertheimer E, Sasson S, Cerasi E, Ben-Neriah Y (1991) The ubiquitous glucose transporter GLUT-1 belongs to the glucose-regulated protein family of stress-inducible proteins. Proc Natl Acad Sci USA 88:2525-2529 